\title{
Pengembangan media pembelajaran interaktif berbasis android pada materi sistem pencernaan untuk siswa SMP kelas VIII
}

\author{
Ervina Mega Silvia, Ibrohim*, Safwatun Nida \\ Universitas Negeri Malang, Jl. Semarang No. 5 Malang, Jawa Timur, Indonesia \\ *Penulis korespondensi, Surel: ibrohim.fmipa@um.ac.id
}

Paper received: 01-03-2021; revised: 15-03-2021; accepted: 31-03-2021

\begin{abstract}
Abstrak
Tujuan penelitian ini adalah menghasilkan media pembelajaran yang valid dan layak pada materi sistem pencernaan manusia untuk siswa SMP kelas VIII. Media pembelajaran ini dapat digunakan untuk belajar secara mandiri oleh siswa. Model penelitian yang digunakan dalam penelitian dan pengembangan ini adalah modifikasi model pengembangan 4-D oleh Thiagarajan (1974) tanpa tahap penyebaran (Disseminate), karena keterbatasan waktu, tenaga, dan biaya. Produk dikemas dalam format apk yang dapat dijalankan pada handphone. Produk hasil pengembangan divalidasi oleh ahli media dan ahli materi, yang selanjutnya diuji cobakan pada limabelas siswa kelas VIII SMP. Jenis data yang diperoleh bersifat kualitatif dan kuantitatif yaitu berupa angket yang disertai saran. Teknik analisis data yang digunakan adalah analisis deskriptif kualitatif. Berdasarkan validasi media oleh validator diperoleh persentase rata-rata sebesar 96,42 persen, artinya media dinyatakan sangat layak untuk digunakan. Berdasarkan validasi materi oleh validator diperoleh persentase rata-rata sebesar 81,67 persen, artinya materi dinyatakan sangat layak untuk digunakan. berdasarkan validasi RPP oleh validator diperoleh presentase rata-rata sebesar 98,43 persen, artinya RPP dinyatakan sangat layak digunakan. Berdasarkan uji keterbacaan pada limabelas siswa dan seorang guru IPA diperoleh persentase rata-rata sebesar 89,05 persen dan 84,52 persen, artinya media dapat dinyatakan sangat layak untuk digunakan dan dapat diuji cobakan dalam skala yang lebih luas
\end{abstract}

Kata kunci: media pembelajaran; IPA; sistem pencernaan manusia

\section{Pendahuluan}

Ilmu Pengetahuan Alam (IPA) merupakan salah satu mata pelajaran yang terdapat pada kurikulum pendidikan nasional di tingkat Sekolah Menengah Pertama (SMP). Pada hakikatnya IPA merupakan ilmu pengetahuan tentang gejala alam yang dituangkan berupa fakta, konsep, prinsip dan hukum yang teruji kebenarannya dan melalui suatu rangkaian kegiatan dalam metode ilmiah. Metode ilmiah tidak hanya berlaku bagi IPA tetapi juga berlaku untuk bidang ilmu lainnya. Hal yang membedakan metode ilmiah dalam IPA dengan ilmu lainnya adalah cakupan dan proses perolehannya. IPA meliputi dua cakupan yaitu IPA sebagai produk dan IPA sebagai proses Yuliati (2008).

Proses pembelajaran IPA perlu memberikan kesempatan siswa untuk mengembangkan potensi yang dimiliki. Di dalam proses pembelajaran IPA, siswa perlu diberi kesempatan untuk mengembangkan potensi yang dimiliki. Keberhasilan proses pembelajaran menentukan kualitas pendidikan (Indriati, 2012). Salah satu prinsip pembelajaran IPA yang tercantum Permendikbud nomor 22 tahun 2016 tentang standar proses, menjelaskan bahwa proses pembelajaran perlu dilakukan secara interaktif dan menarik, serta memberikan ruang yang cukup untuk kemandirian sesuai perkembangan fisik dan psikologis peserta didik.

Kenyataan di lapangan, proses pembelajaran yang interaktif, inspiratif, menyenangkan, menantang, dan memotivasi peserta didik untuk berpartisipasi belum terlaksana secara 
optimal (Lutfi dalam Sari, 2013). Penggunakan metode konvensional seperti ceramah dan tanya jawab di dalam proses pembelajaran tidak dapat membuat pembelajaran menjadi interaktif, inspiratif maupun menyenangkan. Pembelajaran tersebut malah akan membuat siswa cepat bosan apabila guru hanya mengunakan metode mengajar yang monoton (Firdaus, 2013). Selain metode mengajar yang monoton siswa juga sering beranggapan bahwa materi IPA sulit untuk dipahami konsepnya secara teoritis bila tanpa media, melihat langsung, mengamati/melakukan percobaan (Isnaningsih, 2013).

Penerapan pembelajaran secara interaktif dan menarik diharapkan dapat mencapai tujuan pembelajaran IPA yang meliputi memahami, mengkaji, dan menggunakan pengetahuan untuk pemahaman konsep dan fenomena dalam pembelajaran sains (Vieira, dkk., 2011). Pembelajaran IPA yang dilaksanakan di SMP cenderung belum dapat memenuhi tujuan tersebut. Siswa kurang tertarik pada mata pelajaran IPA karena mereka sulit memahami materi tersebut. Siswa masih kesulitan memahami materi IPA yang bersifat abstrak (Ariwibowo \& Parmin, 2015).

Materi IPA yang memerlukan siswa berpikir abstrak salah satunya pada Kompetensi Dasar 3.5 Kelas VIII kurikulum 2013 revisi yang membahas tentang sistem pencernaan manusia. Sistem pencernaan manusia mengandung konsep-konsep yang bersifat mikroskopis sehingga sulit untuk membelajarkan konsep secara verbal dan pengamatan secara langsung. Upaya yang dapat digunakan untuk mengatasi pembelajaran yang mengandung konsepkonsep bersifat mikroskopis adalah dengan menvisualisasikan materi tersebut. Teknik visualisasi yang tepat dapat digunakan guru untuk meningkatkan pemahaman konsep siswa dalam mengilustrasikan konsep yang bersifat abstrak (Andoro, 2015).

Guru juga mengalami kesulitan untuk memberikan gambaran mengenai hal yang abstrak tersebut (Arini, dkk., 2013). Pernyataan Arini, dkk (2013) sesuai dengan hasil wawancara yang peneliti lakukan pada salah satu guru SMP Al-Kautsar. Hasil wawancara menyebutkan bahwa guru masih menggunakan alat peraga, alat praktikum, model, maket serta masih menggunakan buku dan LKS sebagai sumber belajar dalam pembelajaran sehingga membuat siswa kesulitan dalam menvisualisasikan materi sistem pencernaan manusia. Hal ini juga diperkuat dengan hasil analisis pendahuluan melalui angket kebutuhan siswa bahwa 64\% siswa mengatakan bahwa materi sistem pencernaan manusia khususnya proses pencernaan makanan itu sulit sehingga membutuhkan media pembelajaran yang dapat menvisualisasikan dan memahami materi sistem pencernaan manusia. Hasil analisis angket kebutuhan siswa juga mengatakan bahwa $92 \%$ siswa SMP Al-Kautsar sudah memiliki/mengunakan handphone dan $56 \%$ siswa juga menggatakan bahwa mereka menginginkan sebuah media yang dapat membantu dalam proses belajar menggajar.

Media pembelajaran yang dibutuhkan oleh siswa ialah media yang representatif yang dapat di ulang-ulang setiap saat akan dibutuhkan dan media yang memberikan banyak gambar atau video terhadap proses-proses yang ada di dalam sistem pencernaan manusia khususnya proses pencernaan yang tidak dapat divisualisasikan. Sehingga perlu dikembangkan suatu media pembelajaran yang inovatif, portable, serta dapat dimanfaatkan kapanpun dimanapun. Adapun media tersebut ialah media pembelajaran berbasis android. Penggunaan media pembelajaran berbasis android ini selain untuk menvisualisasikan materi yang bersifat abstrak juga mampu meningkatkan keaktifan siswa serta menggurangi pembelajaran yang terpusat pada guru (Bakri, 2011:2). Media ini selain dapat digunakan di 
dalam pembelajaran juga dapat digunakan mandiri oleh siswa dirumah. Siswa dapat memilih materi mana yang akan dipelajari terlebih dahulu namun di anjurkan untuk mempelajari materi secara berurutan.

Media pembelajaran berbasis android dinilai sangat efektif karena aplikasi android saat ini sedang populer dan menjadi salah satu aplikasi yang paling banyak digunakan saat ini (Murtiwiyati, 2013). Selain aplikasi android yang populer, banyak siswa SMP yang sudah menggunakan smartphone beraplikasi android. Banyaknya siswa yang memiliki dan menggunakan perangkat mobile maka semakin besar pula peluang penggunaan perangkat teknologi dalam dunia pendidikan (Gian, 2013). Hal ini juga nantinya memudahkan siswa belajar dengan menggunakan media pembelajaran berbasis android.

Berdasarkan uraian diatas, skripsi ini mengembangkan media pembelajaran interaktif berbasis android yang bertujuan membantu peserta didik dalam memahami suatu materi yang bersifat abstrak di dalam pembelajaran dan memudahkan siswa untuk menggunakan media ini secara berulang-ulang, kapanpun dan dimanapun karena media ini bersifat respresentatif dan portable. Perbedaan dari media pembelajaran sejenis yang sudah ada ialah media milik Yanuanza (2012) yang terletak pada basis, kurikulum dan pendekatan yang digunakan, media ini dapat dijalankan pada perangkat bergerak (mobile device) berbasis android dengan aplikasi emulator yang sudah terdapat pada media yang dikembangkan, terdapat suara pendukung serta banyak animasi gambar, latihan soal yang bersifat interaktif dengan pengguna media, terdapat juga beberapa game puzzle di dalam latihan soal dan media ini sudah menggunakan materi pada kurikulum 2013 revisi. Berdasarkan uraian diatas maka disusunlah skripsi yang berjudul "Pengembangan Media Pembelajaran Interaktif Berbasis Android Materi Sistem Pencernaan Manusia untuk Siswa SMP Kelas VIII".

\section{Metode}

Model penelitian dan pengembangan yang digunakan dalam penelitian ini diadopsi dari model pengembangan 4D (Four-D model) dari Thiagarajan (Thiagarajan dalam Trianto 2013:93). Tahapan-tahapan dari model pengembangan ini ada empat tahap yaitu define, design, develop, dan disseminate atau diadaptasikan menjadi model 4P yaitu pendefinisian, perancangan, pengembangan dan penyebaran. Namun dalam pengembangan media pembelajaran ini hanya dilakukan sampai pada tahap yang ketiga, yakni tahap pengembangan (develop).

Tahap-tahap dalam pengembangan media pembelajaran antara lain, (1) Tahap pendefinisian (define) meliputi analisis awal-akhir, analisis siswa, analisis tugas, analisis konsep, dan perumusan tujuan pembelajaran; (2) Tahap perancangan (design) meliputi penentuan media pembelajaran, pemilihan format, rancangan awal perangkat; (3) Tahap pengembangan (develop) meliputi penilaian validasi oleh ahli (validasi media dan materi), perbaikan atau revisi, dan uji coba kelayakan produk.

Uji validitas dilakukan dua kali, yaitu uji kelayakan media pembelajaran dan uji coba lapangan terbatas. Uji kelayakan media pembelajaran dilakukan oleh ahli media, ahli materi sedangkan uji lapangan terbatas dilakukan kepadaguru SMP dan 15 siswa SMP kelas VIII. Instrumen yang digunakan untuk memperoleh data berupa angket penilaian dalam bentuk checklist yang menilai tampilan media pembelajaran, kebenaran konsep, kesesuaian materi maupun komponen-komponen penyajian materi hasil pengembangan. Jawaban dari angket penilaian tampilan media pembelajaran dan kesesuaian materi menggunakan skala likert 4 
tingkat. Lembar validasi materi (kebenaran konsep) menggunakan skala Guttman yaitu keterangan "ya" dan "tidak" atau "benar" dan "salah". Teknik analisis data yang digunakan adalah teknik analisis persentase. Menentukan nilai (\%) kriteria kelayakan menggunakan rumus sebagai berikut.

$$
P=\frac{\sum x}{n} \times 100 \%
$$

(Sumber: Riduwan, 2004)

Keterangan:

$\mathrm{P}=$ nilai rata-rata dalam persen

$\sum \mathrm{x}=$ jumlah skor penilaian dalam satu aspek

$\mathrm{n}=$ skor tertinggi tiap aspek $\mathrm{x}$ jumlah validator

Setelah ditemukan persentase hasil subjek uji coba, selanjutnya dilakukan pemaknaan terhadap hasil tersebut, terdapat pada Tabel 1 berikut.

Tabel 1 Persentase Hasil Penilaian

\begin{tabular}{lll}
\hline Persentase & Layak & Valid \\
\hline $81 \%-100 \%$ & Sangat layak & Sangat valid \\
$61 \%-80 \%$ & Layak & Valid \\
$41 \%-60 \%$ & Cukup layak & Cukup valid \\
$21 \%-40 \%$ & Tidak layak & Tidak valid \\
$0 \%-20 \%$ & Sangat tidak layak & Sangat tidak valid \\
\hline \multicolumn{3}{c}{ (Sumber : Riduwan, 2006) }
\end{tabular}

\section{Hasil dan Pembahasan}

\subsection{Deskripsi Produk Hasil Pengembangan}

Pengembangan yang dilakukan dalam penelitian ini menghasilkan suatu produk media pembelajaran materi sistem pencernaan manusia. Materi yang terdapat pada media pembeljaran dikembangkan berdasarkan KD yang diperoleh dari Silabus Kurikulum 2013 revisi. Produk ini dapat digunakan sebagai suplemen pembelajaran siswa SMP/ MTs Kelas VIII. Media pembelajaran dikemas dalam bentuk aplikasi (apk) untuk haandphone.

Media pembelajaran yang dikembangkan terdiri dari tampilan awal dan menu utama. Tampilan awal terdiri dari identitas media pembelajaran dan petunjuk penggunaan media. Tampilan menu utama terdiri dari menu "KI dan KD", menu "Petunjuk Pengunaan", menu "Materi", serta menu "Evaluasi". Menu "KI dan KD!" berisi Kompetensi Inti dan Kompetensi Dasar yang akan dicapai. Menu "Petunjuk Pengunaan" berisi penjelaskan arti dari tombol-tombol yang terdapat dalam media pembelajaran. Menu "Materi" berisi materi yang akan dipelajari. Menu evaluasi" berisi soal-soal yang disajikan pada media. Cakupan materi pada media pembelajaran interaktif berbasis android terdiri dari nutrisi dalam makanan, organ pencernaan, 
mekanisme pencernaan, gangguan dan cara mengatasi penyakit pada sistem pencernaan. Setiap materi dilengkapi dengan penyajian animasi, dan gambar. Khusus materi mekanisme pencernaan terdapat video proses pencernaan makanan

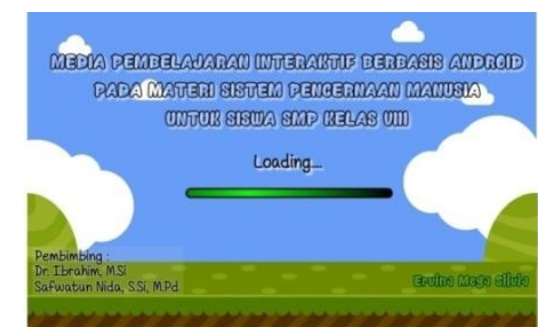

Tampilan Halaman Awal Media Pembelajaran (Cover)

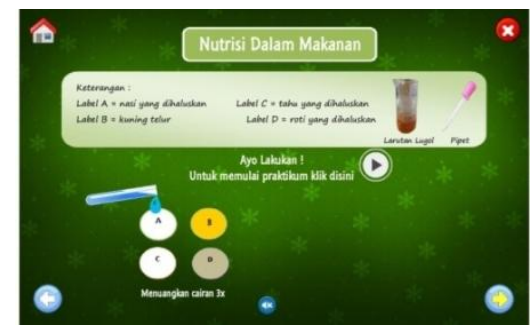

Tampilan praktikum uji makanan pada Media

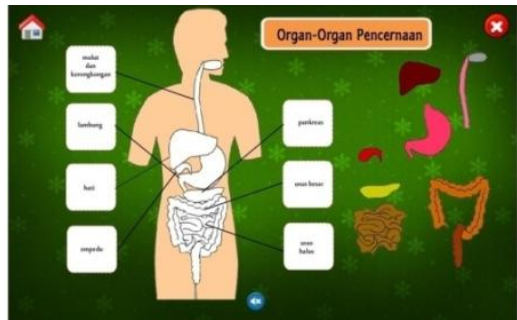

Tampilan Game Mencocokkan Nama Organ

\section{Gambar 1. Tampilan Produk Media Pembelajaran}

\subsection{Hasil Validasi Produk}

Uji validasi dilaksanakan oleh satu dosen Biologi Universitas Negeri Malang. Data kuantitatif hasil uji validasi materi dibedakan menjadi dua, yaitu data uji validasi kebenaran konsep dan data uji validasi kesesuaian materi. Data kuantitatif hasil uji validasi kebenaran konsep dapat dilihat pada Tabel 2 berikut.

Tabel 2 Data Kuantitatif Hasil Uji Validasi Kebenaran Konsep

\begin{tabular}{lll}
\hline No & Konsep & Nilai (\%) \\
\hline 1. & Pendahuluan (Sistem & $100 \%$ \\
& Pencernaan) & \\
2. & Subbab Nutrisi Dalam Makanan & $100 \%$ \\
3. & Subbab Organ Pencernaan & $100 \%$
\end{tabular}




\begin{tabular}{lll} 
4. Subbab Mekanisme Pencernaan & $100 \%$ \\
5. & Subbab Gangguan pencernaan & $100 \%$ \\
\hline Nilai Rata-rata & $100 \%$ \\
\hline
\end{tabular}

Berdasarkan data hasil kebenaran konsep pada media pembelajaran ini memperoleh persentase sebesar $100 \%$. Media pembelajaran dapat dikatakan layak jika tidak terdapat kesalahan konsep, sehingga dari hasil persentase tersebut, media pembelajaran yang dikembangkan sudah layak untuk digunakan. Uji validasi materi selanjutnya adalah tentang kesesuaian materi. Data kuantitatif hasil uji validasi kesesuaian materi dapat dilihat pada Tabel 3 berikut.

Tabel 3 Data Kuantitatif Hasil Uji Validasi Kesesuaian Materi dan Tingkat Kelayakan

\begin{tabular}{|c|c|c|c|c|}
\hline No & Aspek yang dinilai & Rerata & Nilai (\%) & $\begin{array}{l}\text { Tingkat } \\
\text { Kelayakan }\end{array}$ \\
\hline 1. & Desain Pembelajaran & 4,00 & 100,00 & Sangat Layak \\
\hline 2. & Kejelasan Materi & 3,00 & 75,00 & Sangat Layak \\
\hline 3. & $\begin{array}{l}\text { Kesesuaian Gambar dengan } \\
\text { Materi }\end{array}$ & 3,25 & 81,25 & Sangat Layak \\
\hline 4. & $\begin{array}{l}\text { Kesesuaian Video dengan } \\
\text { Materi }\end{array}$ & 4,00 & 100,00 & Sangat Layak \\
\hline 5. & Keluasan Materi & 3,00 & 75,00 & Sangat Layak \\
\hline 6. & $\begin{array}{l}\text { Kemudahan dalam } \\
\text { Memahami Materi }\end{array}$ & 3,00 & 75,00 & Sangat Layak \\
\hline 7. & $\begin{array}{l}\text { Kesesuaian Soal } \\
\text { Pemahaman Konsep }\end{array}$ & 3,75 & 93,75 & Sangat Layak \\
\hline 8. & Soal Evaluasi & 4,00 & 100,00 & Sangat Layak \\
\hline \multicolumn{2}{|c|}{ Nilai Rata-rata } & 3,5 & 81,67 & Sangat Layak \\
\hline
\end{tabular}

Berdasarkan Tabel 3, persentase kesesuaian materi yang terdapat pada media pembelajran memperoleh hasil sebesar $81,67 \%$ dan dinyatakan bahwa kesesuaian materi sangat layak. Namun, terdapat saran dari validator materi untuk perbaikan kebenaran konsep maupun kesesuaian materi yang ada pada media pembelajaran. Saran pembenaran kesesuaian materi dapat dilihat pada Tabel 4 berikut.

Tabel 4 Data Kualitatif Hasil Uji Validasi Materi (Kesesuaian Materi)

\begin{tabular}{ll}
\hline No & Saran Validator \\
\hline 1. & Kalimat pada soal evaluasi perlu diperpanjang \\
2. & Penambahan tabel bagian organ pada organ pencernaan \\
3. & Gambar kerongkongkan sebaiknya yang lebih jelas \\
\hline
\end{tabular}

Kegiatan validasi media pembelajaran menghasilkan data kuantitatif dan data kualitatif. Data kuantitatif hasil uji validasi media dapat dilihat pada Tabel 5 berikut. 
Tabel 5 Data Kuantitatif Hasil Uji Validasi Media dan Tingkat Kelayakan

\begin{tabular}{lllll}
\hline No & Aspek yang dinilai & Rerata & Nilai (\%) & Tingkat Kelayakan \\
\hline 1. & Tampilan Media Pembelajaran & 3,80 & 95,00 & Sangat Layak \\
2. & Penyajian Gambar & 4,00 & 100,00 & Sangat Layak \\
3. & Penyajian Video & 3,67 & 91,67 & Sangat Layak \\
4. & Penyajian Soal Pemahaman & 4,00 & 100,00 & Sangat Layak \\
& Konsep & & & \\
5. & Penyajian Soal Evaluasi & 4,00 & 100,00 & Sangat Layak \\
6. & Rekayasa Perangkat Lunak & 4,00 & 100,00 & Sangat Layak \\
7. & Komunikasi Visual & 3,75 & 93,75 & Sangat Layak \\
\hline Nilai Rata-rata & 3,88 & 96,42 & Sangat Layak \\
\hline
\end{tabular}

Berdasarkan data hasil uji validasi media, media pembelajaran yang telah dikembangkan memperoleh hasil rerata sebesar 96,42\% dan dinyatakan bahwa media sangat layak. Selain data kuantitatif, validator juga memberikan data kualitatif berupa saran dan komentar yang digunakan untuk perbaikan media pada bahan ajar digital. Saran tersebut dapat dilihat pada Tabel 6 berikut.

Tabel 6 Data Kualitatif Hasil Uji Validasi Media

\begin{tabular}{ll}
\hline No & Saran Validator \\
\hline 1. & Perjelaas tulisan \\
2. & Perbaiki tulisan yang salah ketik \\
3. & Gambar anak pada halaman awal sebaiknya diganti dengan gambar \\
& anak indonesia \\
4. & Perjelaas tulisan
\end{tabular}

Data kuantitatif hasil uji validasi RPP dapat dilihat pada Tabel 7 berikut.

Tabel 7 Data Kuantitatif Hasil Uji Validasi RPP dan Tingkat Kelayakan

\begin{tabular}{lllll}
\hline No & Aspek yang dinilai & Rerata & Nilai (\%) & Tingkat Kelayakan \\
\hline 1. & Format RPP & 4,00 & 100,00 & Sangat Layak \\
2. & Komponen RPP & 4,00 & 100,00 & Sangat Layak \\
3. & Prinsip Penyusunan RPP & 3,80 & 95,00 & Sangat Layak \\
\hline Nilai Rata-rata & 3.93 & 98,43 & Sangat Layak \\
\hline
\end{tabular}

Berdasarkan data hasil uji validasi RPP, RPP yang telah dikembangkan memperoleh hasil rerata sebesar 98,43\% dan dinyatakan bahwa RPP sangat layak. Selain data kuantitatif, validator juga memberikan data kualitatif berupa saran dan komentar yang digunakan untuk perbaikan RPP. Saran tersebut dapat dilihat pada Tabel 8 berikut.

Tabel 8 Saran dan Komentar Hasil Uji Keterbacaan bahan Ajar Digital oleh Siswa

\begin{tabular}{ll}
\hline No & Saran dan Komentar Validator \\
\hline 1. & Perbaiki kata-kata yang salah ketik
\end{tabular}




\subsection{Hasil Uji Keterbacaan}

Uji keterbacaan media pembelajaran dilakukan pada 1 Guru SMP dan 15 siswa SMP kelas VIII. Hasil uji keterbacaan dapat dilihat pada Tabel 11 berikut.

Tabel 9 Data Kuantitatif Hasil Uji Keterbacaan pada Guru dan Tingkat Kelayakan

\begin{tabular}{|c|c|c|c|c|}
\hline No & Aspek yang dinilai & Rerata & Nilai (\%) & Tingkat Kelayakan \\
\hline 1. & Tampilan Media Pembelajaran & 3,83 & 95,83 & Sangat Layak \\
\hline 2. & Penyajian Gambar & 3,00 & 75,00 & Sangat Layak \\
\hline 3. & Penyajian Video & 3,33 & 83,33 & Sangat Layak \\
\hline 4. & $\begin{array}{l}\text { Penyajian Soal Pemahaman } \\
\text { Konsep }\end{array}$ & 3,00 & 75,00 & Sangat Layak \\
\hline 5. & Penyajian Soal Evaluasi & 3,00 & 75,00 & Sangat Layak \\
\hline 6. & Rekayasa Perangkat Lunak & 3,33 & 83,33 & Sangat Layak \\
\hline 7. & Komunikasi Visual & 3,25 & 81,25 & Sangat Layak \\
\hline \multicolumn{2}{|c|}{ Nilai Rata-rata } & 3,24 & 81,24 & Sangat Layak \\
\hline
\end{tabular}

Berdasarkan data hasil uji keterbacaan pada guru memperoleh hasil rerata sebesar $81,24 \%$ dan dinyatakan bahwa media pembelajaran sangat layak untuk digunakan.

Tabel 10 Data Kuantitatif Hasil Uji Keterbacaan pada Siswa dan Tingkat Kelayakan

\begin{tabular}{lllll}
\hline No & Aspek yang dinilai & Rerata & Nilai (\%) & Tingkat Kelayakan \\
\hline 1. & Tampilan Media & 3,56 & 89,16 & Sangat Layak \\
& Pembelajaran & & & \\
2. & Penyajian Materi & 3,40 & 86,66 & Sangat Layak \\
3. & Penyajian Soal Evaluasi & 3,53 & 88,33 & Sangat Layak \\
4. & Komunikasi Visual & 3,59 & 92,08 & Sangat Layak \\
\hline Nilai Rata-rata & 3,55 & 89,05 & Sangat Layak \\
\hline
\end{tabular}

Berdasarkan data hasil uji keterbacaan pada siswa memperoleh hasil rerata sebesar $89,05 \%$ dan dinyatakan bahwa media pembelajaran sangat layak untuk digunakan. Saran yang diberikan oleh siswa dapat dilihat pada Tabel 11 berikut.

Tabel 11 Saran dan Komentar Hasil Uji Keterbacaan oleh Siswa

\begin{tabular}{ll}
\hline No & Saran dan Komentar Siswa \\
\hline 1. & Sebaiknya font pada media pembelajaran ini diperbesar
\end{tabular}

\section{Simpulan}

\subsection{Kesimpulan}

Produk yang dihasilkan dalam penelitian dan pengembangan ini adalah Media Pembeajaran Interaktif Berbasis Android pada Materi Sistem Pencernaan Manusia untuk Siswa SMP Kelas VIII. Media pembelajaran ini terdiri dari empat subbab, yaitu subbab nutrisi dalam makanan, organ pencernaan, mekanisme pencernaan, gangguan pencernaan dan pencegahannya. Pada setiap subbab materi diawali dengan apersepsi atau pemberian masalah melalui gambar maupun pertanyaan yang sesuai dengan subbab yang akan dibahas. Selain itu, akan disajikan uji pemahaman konsep untuk mengecek pemahaman siswa setelah mempelajari materi didalam media 
pembelajaran. Produk akhir dari media pembelajaran akan dikemas dalam bentuk APK(aplikasi).

Berdasarkan hasil Uji Validasi diperoleh presentase sebesar 98,43\% untuk RPP, sehingga dapat dinyatakan bahwa RPP valid dan layak digunakan dalam media pembelajran ini. Validasi produk diperoleh persentase sebesar $100 \%$ untuk kebenaran konsep dan 81,67\% untuk kesesuaian materi, sehingga dapat dinyatakan bahwa materi yang ada pada media pembelajaran ini sangat valid dan sangat layak. Hasil validasi media oleh ahli media, diperoleh persentase kelayakan sebesar 96,42\%, sehingga dapat dinyatakan bahwa media pembelajaran sangat layak dan sangat valid.. Berdasarkan hasil uji keterbacaan pada 1 guru IPA SMP dan 10 siswa SMP Kelas VIII diperoleh persentase kelayakan media pembelajaran sebesar $84,52 \%$ dan $89,05 \%$ sehingga dapat dinyatakan bahwa media pembelajaran yang dikembangkan sangat layak untuk digunakan. Sehingga dapat disimpulkan bahwa penelitian dan pengembangan ini menghasilkan produk berupa media pembelajran berbasis android materi sistem pencernaan manusia untuk siiswa SMP kelas VIII yang valid dan layak.

\subsection{Saran}

Saran pengembangan lebih lanjut adalah peneliti lain dapat memadukan media pembelajaran ini, sehingga tidak hanya materi biologi, tetapi juga dikaitkan dengan fisika maupun kimia. Pengembangan lebih lanjut dapat dilakukan uji coba secara empirik dengan sampel yang lebih luas. Uji empirik dilakukan untuk mengetahui keefektifan media pembeajaran ini dalam pembelajaran IPA.

\section{Daftar Rujukan}

Andoro, I. F. B. (2015). Proses Visualisasi Sistem Operasi Berbasis Multimedia dengan Metode Kognitif Piaget di SMK Ibu Kartini Semarang. Jurnal IC-Tech, 10(2), 52-59.

Arini, Y. D., \& Dayani, S. (2013). Visualisasi 3 Dimensi Sistem Peredaran Darah Manusia Menggunakan Teknik Low Poly dan Particle System (Study Kasus: SDN Bintaro 01 Pagi).JURNAL TEKNIK INFORMATIKA, 6(2).

Bakri, H. (2011). Desain media pembelajaran animasi berbasis adobe flash CS3 pada mata kuliah instalasi listrik 2. Jurnal Medtek, 3(2), 3-4.

Bimo, D. S. (2013). Penerapan lembar kegiatan siswa (LKS) discovery berorientasi keterampilan proses sains untuk meningkatkan hasil belajar IPA. Jurnal Pendidikan IPA Indonesia, 2(2).

Glenn Lauren, Murtiwiyati (2013). Rancang Bangun Aplikasi Pembelajaran Budaya Indonesia Untuk Anak Sekolah Dasar Berbasis Android, 12, 2, 25 December 2013

No, J. S. (2014). Pengembangan media pembelajaran monopoli IPA materi sistem pencernaan makanan untuk siswa kelas VIII di SMP Negeri 4 Malang.

Oktiana, G. D. (2015). Pengembangan media pembelajaran berbasis android Dalam bentuk buku saku digital untuk mata pelajaran Akuntansi kompetensi dasar membuat ikhtisar siklus Akuntansi perusahaan jasa di kelas xi man 1 Yogyakarta tahun ajaran 2014/2015. Skripsi tidak diterbitkan (online). Yogyakarta: Jurusan Pendidikan Akuntansi Universitas Negeri Yogyakarta.

SCP, D. I. (2012). Meningkatkan Hasil Belajar IPA Konsep Cahaya Melalui Pembelajaran Science-Edutainment Berbantuan Media Animasi. Jurnal Pendidikan IPA Indonesia, 1(2).

Pendidikan, K., \& Indonesia, K. R. (2016). Permendikbud Nomor 22 Tahun 2016 Tentang Standar Proses Pendidikan Dan Menengah. Jakarta: Kemendikbud.

Riduwan, M. B. A. (2006). Belajar mudah penelitian untuk guru-karyawan dan peneliti pemula. Bandung: Alfabeta.

Sari, M. (2013). Problematika pembelajaran sains ditinjau dari aspek guru. Al-Ta lim Journal, 20(1), 346-356. 
Trianto, M. P. (2012). Model Pembelajaran Terpadu: Konsep, Strategi dan Implementasinya.

Vieira, R. M., Tenreiro-Vieira, C., \& Martins, I. P. (2011). Critical thinking: Conceptual clarification and its importance in science education. Science education international, 22(1), 43-54.

Wismadi, R. H. (2013). Penggunaan Multimedia Interaktifdalam Pembelajaran Ipa Di SMP. Jurnal Ilmiah Guru Caraka Olah Pikir Edukatif, (1).

YANURIZNA, M. Y. (2012). Pengembangan Media Interaktif dengan Tema Sistem Pencernaan Manusia Untuk SMP Kelas VIII. Pensa e-jurnal: pendidikan sains, 1(01).

Yuliati, L. (2008). Model-model Pembelajaran Fisika: Teori dan Praktek. Malang: LP3 Universitas Negeri Malang. 